\title{
FUNCTIONAL CHANGES OF TESTES IN LEAD INTOXICATED RATS
}

\author{
A. ROY CHOWDHURY, R. V. RAO, A. K. GAUTAM \\ and S. K. KASHYAP \\ National Institute of Occupational Health, \\ Meghani Nagar, Ahmedabad 380016, India.
}

(Received April 21, 1986 and in revised form February 17, 1987)

\begin{abstract}
Lead acetate treatment intraperitoneally at the dosages of $1 \mathrm{mg}, 2 \mathrm{mg}$, $4 \mathrm{mg}$ and $6 \mathrm{mg} / \mathrm{kg}$ over a period of 30 days altered spermatogenesis in rats. Inhibition of $\Delta^{5}$-3 $\beta$-hydroxysteroid dehydrogenase was parallel with the high concentration of testicular cholesterol and low concentration of ascorbic acid, alkaline phosphatase and protein in most of the treated groups. Gradual increase in blood and testis lead alongwith the proportional inhibition of $\delta$-aminolevulinic acid dehydratase levels indicated the intensity of lead toxicity in rats. Data revealed that alteration of spermatogenesis in lead treated rats might be due to the inhibition of steroidogenesis.
\end{abstract}

Key words : Lead acetate-Spermatogenesis-Steroidogenesis testes-Leydig cells

\section{INTRODUCTION}

Reproductive abnormalities in experimental animals treated with lead acetate have already been documented both in males and females. ${ }^{1,2)}$ Sperm motility was impaired in semen samples from rats with blood lead concentrations exceeding $39 \mu \mathrm{g} / 100 \mathrm{ml}^{3}{ }^{3}$ Moreover, rats, guinea pigs and rabbits showed the impairment of testicular function after treatment with lead acetate. ${ }^{4)}$ Little information is available whether these observations are due to direct effect of lead on spermatogenesis or through inhibition of steroidogenesis. Present investigation was undertaken to contribute a better understanding of the testicular function with different dosages of lead acetate treatment in rats.

\section{Materials AND Methods}

Experimental design: Ninety male albino rats of Charles Foster Strain, weighing $150 \pm 5 \mathrm{~g}$ were obtained from National Institute of Occupational Health breeding colony. Animals were divided into five equal groups (18 rats/group) and maintained under uniform experimental conditions. Group I served as control, while Group II, III, IV and V received aqueous solution of lead acetate daily 
intraperitoneally (i.p.) at the dosage of $1 \mathrm{mg}, 2 \mathrm{mg}, 4 \mathrm{mg}$ and $6 \mathrm{mg} / \mathrm{kg}$ body weight respectively over a period of 30 days. Control animals received distilled water as per the experimental schedule. Initial and final body weight of control as well as experimental groups were recorded.

Biochemical estimations: On 31st day, prior to sacrifice, the animals were anaesthetised by solvent ether and blood was collected from retro-orbital venous plexus in heparinized vials for the estimation of blood lead by Atomic Absorption Spectrophotometry. ${ }^{5)} 0.2 \mathrm{ml}$ of blood was used for the estimation of $\delta$-aminolevulinic acid dehydratase (ALA-D). ${ }^{6)}$

After decapitation of animals, testes were cleanly dissected out and weighed. Five testes from each group were collected and separately digested with concentrated nitric acid for the determination of testicular lead by Atomic Absorption Spectrophotometer. ${ }^{7)}$ Fifteen testes from each group were homogenized separately in ice cold distilled water and the clean supernatant was obtained after centrifugation. From this supernatant the testicular ascorbic acid, protein and alkaline phosphatase (ALK.Pase) were estimated by the methods of Roe and Kuether, ${ }^{3)}$ Lowry et al. ${ }^{9)}$ and Bodansky, ${ }^{10)}$ respectively.

Five testes from each group were homogenized in chloroform ethanol mixture (2:1) and the testicular cholesterol was estimated according to Sperry and Webb. ${ }^{11)}$

Histological and histometrical study: Six testes from each group were fixed in $10 \%$ neutral formalin, embedded in paraffin and $5 \mu \mathrm{m}$ thick sections were stained with periodic acid Schiff's (PAS) and hematoxylin for the microscopical examination. VIIth stage of spermatogenesis was assessed quantitatively due to clear microscopical view of acrosomes in spermarids. ${ }^{12)}$ 8.5 Sertoli cells per tubular cross-section were considered as standard. Seminiferous tubular diameter was measured by occular micrometer at $160 \times$ magnification. Leydig cell nuclear diameter was determined at $640 \times$ magnification. ${ }^{13)}$

Histochemical study: Fresh frøzen $8 \mu \mathrm{m}$ thick cryostatic sections of testes were mounted on coverslips and processed to note the activity of $\Delta^{5}-3 \beta$-hydroxysteroid dehydrogenase $\left(\Delta^{5}-3 \beta\right.$-OHSD). $\left.{ }^{14}\right)$ Control sections were incubated in substrate free media.

Statistical analysis: Statistical significance was determined by Student's t-test.

\section{RESUlts}

Increasing doses of lead acetate produced a gradual decrease in body as well as in testicular weight in all experimental groups (Table 1). Blood and testicular 


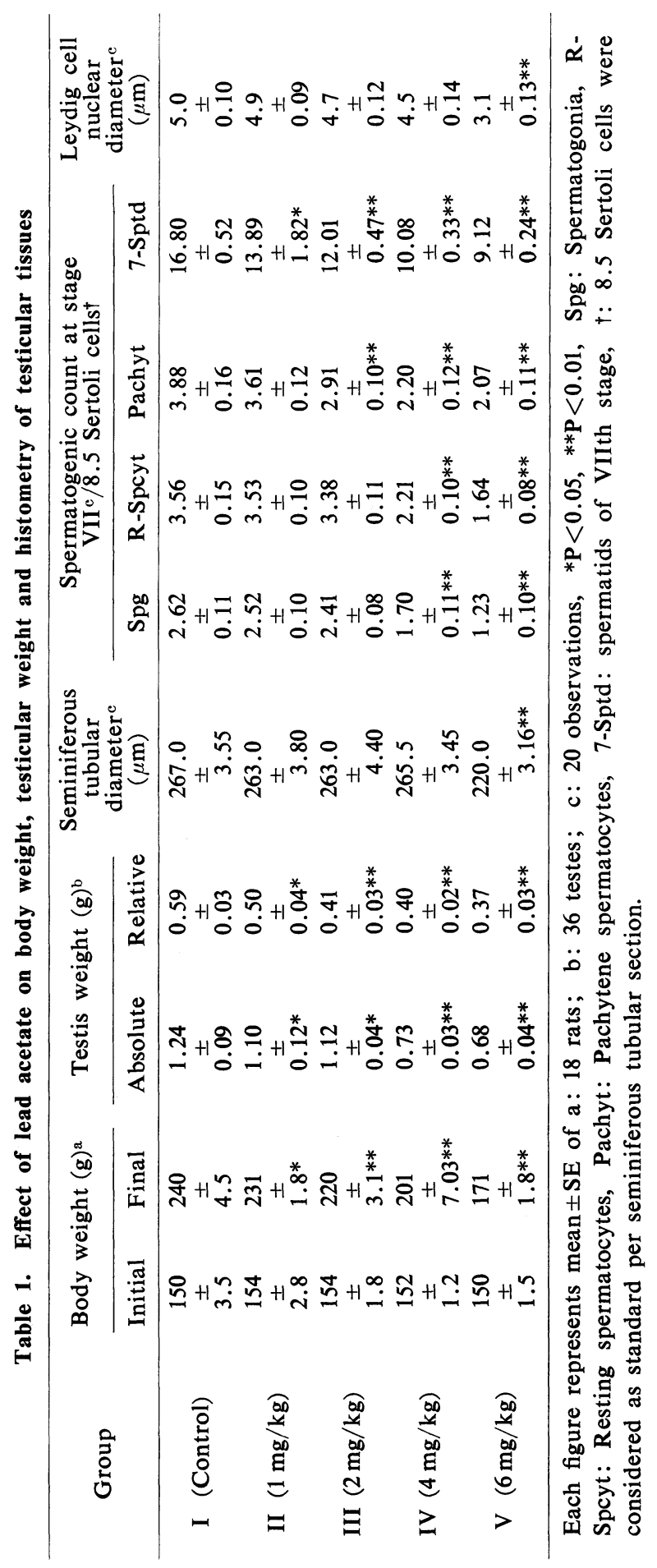




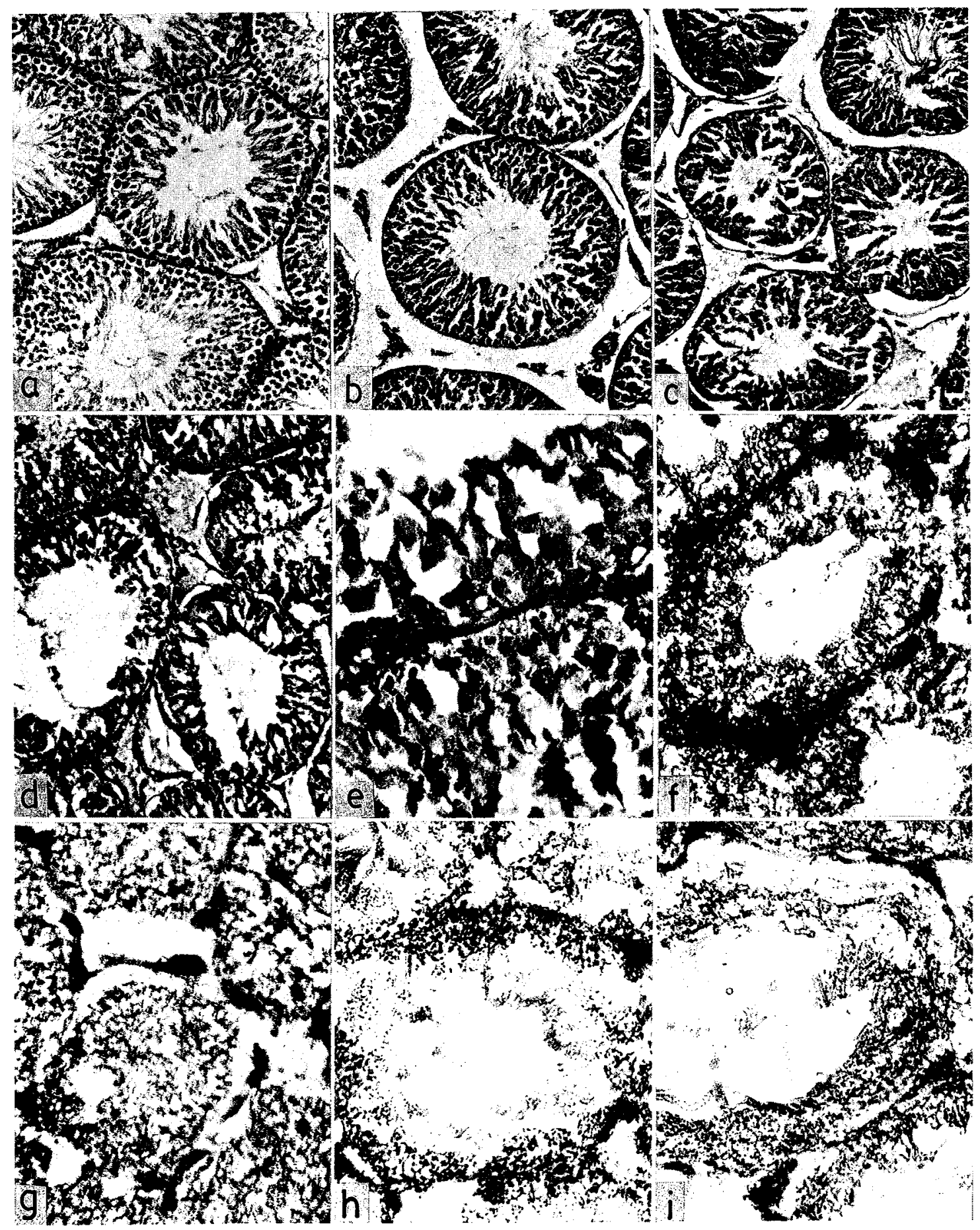


lead exhibited a significant increase and inhibition of ALA-D was observed in treated animals (Table 2).

Increase in testicular cholesterol and decrease in ascorbic acid, ALK.Pase and protein were observed in Group III, IV and V (Table 2).

In Group II, significant decline of spermatids was noted and there was no alteration of other spermatogenic cells as compared to control (Fig. 1a; Table 1). Inhibition of post meiotic spermatogenic cells namely; pachytene spermatocytes and spermatids was observed in Group III (Fig. 1b; Table 1). Spermatogenic cell count was significantly decreased in Group IV and V (Table 1). Germinal cell layer detachment from basal membrane and injury of spermatocytes and spermatids were exhibited in Group IV (Fig. 1c). Significant degenerative changes and interstitial oedema were observed alongwith atrophy of Leydig cells in Group V (Fig. 1d, e). Moreover, the seminiferous tubular diameter and Leydig cell nuclear diameter were also decreased significantly in Group V (Table 1).

Gradual decrease of testicular $\Delta^{5}-3 \beta$-OHSD activity was noted in all experimental groups as compared to control (Fig. 1f, g, h, i).

\section{Discussion}

The retardation of body and testicular weight of rats after lead treatment may possibly be due to relative intensities of lead toxicity which was determined by gradual increase in blood and testis lead and correspondingly the inhibition of blood ALA-D. ${ }^{15)}$ Administration of lead in rats and rabbits caused marked

Figure 1. a : Section of normal rat testis showing arrangement of spermatogenic cells in the seminiferous tubules and Leydig cells $(\times 160)$.

b : Post meiotic spermatogenic inhibition in rat testis treated with $2 \mathrm{mg} / \mathrm{kg}$ (i. p.) body weight lead acetate over a period of 30 days $(\times 160)$.

c : Inhibition of spermatogenesis and detachment of germinal cell layers in the testis of rat received $4 \mathrm{mg} / \mathrm{kg}$ (i. p.) body weight lead acetate $(\times 160)$.

d: Marked degenerative changes in spermatogenic cells and atrophy of Leydig cells in rat treated with $6 \mathrm{mg} / \mathrm{kg}(\mathbf{i}$. p.) lead acetate $(\times 160)$.

e : Marked deplition of the spermatogenic cells after $6 \mathrm{mg} / \mathrm{kg}$ lead acetate treatment for 30 days $(\times 640)$.

f : Showing normal activity of $\Delta^{5}-3 \beta$-OHSD in testicular tissue of control rat $(\times 160)$.

g: Rats treated with $2 \mathrm{mg} / \mathrm{kg}$ lead acetate (i. p.) daily for 30 days showing slight deplition of $\Delta^{5-3} \beta$-OHSD activity in the testicular tissue $(\times 160)$.

$h$ : Administration of $4 \mathrm{mg} / \mathrm{kg}$ lead acetate (i. p.) daily for 30 days, showing less $\Delta^{5-3} \beta$-OHSD activity in the testis of rat $(\times 160)$.

i : Significant inhibition of $\Delta^{5-3} \beta-$ OHSD activity in the testicular tissue after treatment with $6 \mathrm{mg} / \mathrm{kg}$ (i. p.) lead acetate daily over a period of 30 days $(\times 160)$. 


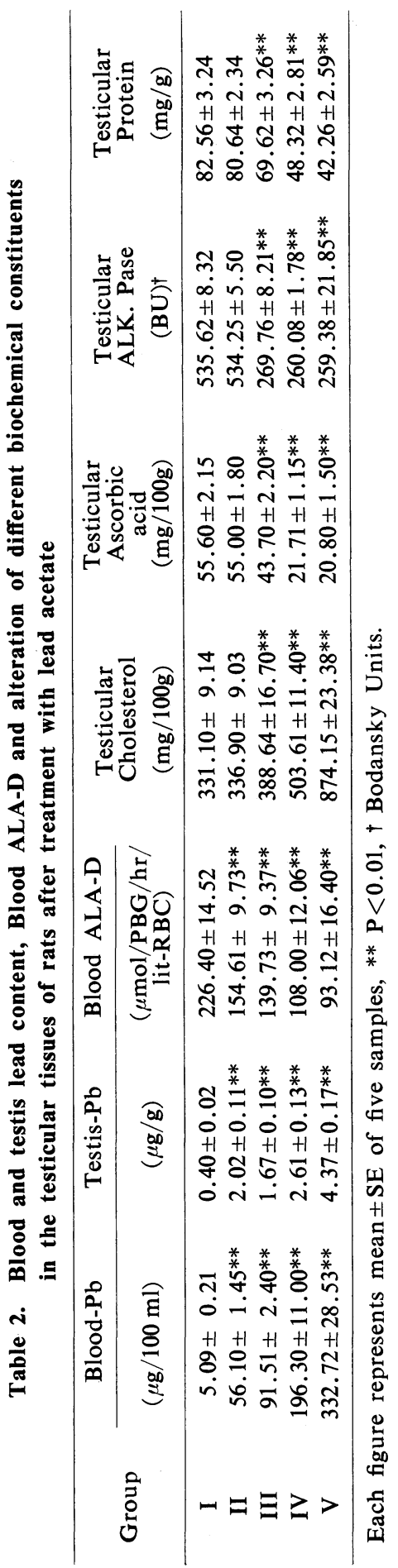


decrease in testicular weight and degeneration of spermatogenic cells. ${ }^{16)}$ Equivocal observations in Group IV and V may possibly be due to significant decrease of testicular protein. Prolonged administration of lead to rats caused significant decrease in liver and kidney protein content. ${ }^{17)}$ Relative deposition of lead in testicular tissues caused significant decrease in protein content alongwith cellular degeneration in Group III, IV and V. The ALK.Pase in the testes is mainly associated with the structural integrity of the basement membrane of the seminiferous tubules. ${ }^{18)}$ The inhibition of testicular ALK.Pase in Group III, IV and $\mathrm{V}$ were associated with the regression of basement membrane of the seminiferous tubules which was confirmed by histological findings.

The testosterone is synthesized from cholesterol in Leydig cells. ${ }^{19)}$ Leydig cell degeneration and significant increase in testicular cholesterol in treated groups suggest the failure of testosterone synthesis. A clinical study revealed that serum testosterone levels were significantly reduced in lead exposed men. ${ }^{20}$ Ascorbic acid plays an important role in the process of steroidogenesis ${ }^{21)}$ and $\Delta^{5}-3 \beta$-OHSD is key enzyme for the same process. ${ }^{22)}$ Significant fall of ascorbic acid and gradual inhibition of $\Delta^{5}-3 \beta$-OHSD alongwith accumulation of cholesterol suggest the inhibition of steroidogenesis in the testes of lead exposed rats.

\section{ACKNOWLEDGEMENT}

Authors are grateful to Indian Council of Medical Research, New Delhi for providing the funds to conduct this study.

\section{REFERENCES}

1) Hilderbrand DC, Der R, Griffin WT, Fahim MS. Effect of lead acetate on reproduction. Am J Obstet Gynecol 1973; 115: 1058-65.

2) Stowe HD, Goyer RA. The reproductive ability and progeny of $F_{1}$ lead-toxic rats. Fertil Steril 1971; 22: 755-60.

3) Eyden BP, Maisin JR, Mattelin G. Long term effects of dietary lead acetate on survival, body weight and seminal cytology in mice. Bull Environ Contam Toxicol 1978; 19: 266-72.

4) Morris, HP, Lang EP, Morris HI. The growth and reproduction of rats fed with diet containing lead acetate and arsenic trioxide and the lead arsenic content of new born and adult suckling rats. J Pharmacol Exp Ther 1938; 64: 420-5.

5) Delves HT. A micro sampling method for the rapid determination of lead in blood by atomic absorption spectrophotometry. Analyst 1970; 95: 431-8.

6) Nakagawa $K$, Asami $M$, Kuriyama $K$. Inhibition of lysosomal enzymes in young rat brain by lead acetate. Toxicol Appl Pharmacol 1980; 56; 86-92.

7) Mylroe AA, Moore L, Erogbigbo V. Influence of dietary factors on blood and tissue lead concentrations and toxicology. Toxicol Appl Pharmacol 1977; 41: 361-77.

8) Roe JH, Kuether CA. The determination of ascorbic acid in whole blood and urine through the 2,4-dinitrophenyl hydrazine derivatives of dehydroascorbic acid. J Biol Chem 1943; 147: 399-411. 
9) Lowry OH, Rosenbrough NJ, Farr AL, Randall RJ. Protein measurement with the Folin Phenol reagent. J Biol Chem 1951; 193: 265-75.

10) Bodansky A. Determination of inorganic phosphate Beer's Law and interfering substances in Kuttner lien tenstein method. J Biol Chem 1932; 99: 197-204.

11) Sperry WM, Webb M. A revision of the schoenheimer sperry method for the cholesterol determination. J Biol Chem 1950; 187: 97-100.

12) Leblond CP, Clermont Y. Definition of the stages of the cycle of the seminiferous epithelium in the rat. Ann New York Acad Sci 1952; 55: 548-73.

13) Chowdhury AR, Chatterjee AK. Effect of adrenalectomy on the testicular cells of immature rats. Indian J Exp Biol 1978; 16: 88-9.

14) Tso ECF, Lofts B. Seasonal variation in Newt testis, histological and histochemical study. Acta Zoologica 1977; 58: 128.

15) Millar JA, Battistini V, Cumming RLC, Carswell F, Goldberg A. Lead and $\delta$-aminolevulinic acid dehydratase levels in mentally retarded children and in lead poisoned suckling rats. Lancet 1970; 2: 695-8.

16) Roy Chowdhury A, Dewan A, Gandhi DN. Toxic effect of lead on the testes of rat. Biomed Biochem Acta 1984; 43: 95-100.

17) Choie DD, Richter GW. Cell proliferation in mouse kidney induced by lead. 1. Synthesis of deoxyribonucleic acid and protein. Lab Invest. 1974; 30: 647-51.

18) Santiemma V, Francavilla S, Francavilla F, Santucci R, Onori D, Bellocci M, Fabbrini A. Development and hormone dependence of peritubular smooth muscle cells of the rat testis; In Recent Progress in Andrology, ed. by Fabbrini A, Steinberger E, 1978; 185.

19) Bartke A. Pituitary-testis relationships. Reprod Biol 1976; 1: 136-52.

20) Braunstein GD, Dahlgren J, Loriaux DL. Hypogonadism in chronically lead-exposed men. Infertility 1978; 1: 33-57.

21) Biswas NM, Deb C. Role of ascorbic acid in testicular degeneration and adrenal hypertrophy in tyrosine fed rats. Endocrinology 1966; 76: 1157-9.

22) Baillie AH, Mack WS. Hydroxysteroid dehydrogenases in normal and abnormal human testes. J Endocrinol 1966; 35: 239-48. 